\title{
Exchange Rate And Its Effect On Foreign Currencies And Price Indices
}

\author{
Salahedeen Ramadan Azwali
}

Phd. candidate

DOI: 10.29322/IJSRP.11.01.2021.p10970

http://dx.doi.org/10.29322/IJSRP.11.01.2021.p10970

\begin{abstract}
The exchange rate is one of the most sensitive instruments of economic policy. The exchange rate policy of each country contains two relations: the ratio of the exchange rate to all other parameters of economic policy, which is the internal economic and political component of exchange rate policy and the ratio of national currency to the currencies of other countries, which is the interval component of the exchange rate.
\end{abstract}

Index Terms- Monetary policy, exchange rate, prices

\section{INTRODUCTION}

A lthough it has several functions, the exchange rate is basically the price of one currency expressed in units of another currency. Without the existence of exchange rates, therefore, it would not be possible to convert the mutual value of different currencies and there would be no international business under the conditions of the existence of several national currencies. This is also the main and most obvious function of the exchange rate.

\section{FUNCTIONS OF THE EXCHANGE RATE}

The remaining two exchange rate functions could not be said to be less important than the basic ones. Thus, the exchange rate in its second function serves to compare prices. This function naturally springs from the first, because otherwise it would not make sense to compare only the value of currencies. Although, in addition to goods and services, there are financial transactions between residents from different countries (capital movements that are autonomously motivated; it often happens that they condition compensatory movement of goods) which have long exceeded goods and services and whose volume ranges from at a level many times higher than commodity-service transactions, the exchange rate serves to compare prices. It is not an exaggeration to say that the third function of the exchange rate is the crown in the functioning of the unity of the functions of the exchange rate. According to that function, the exchange rate is one of the most important parameters in the successful allocation of resources. Namely, since it is used to convert foreign to domestic prices, the exchange rate allows, in addition to internal, to include in each calculation external criteria important for the allocation of resources. In conditions of very dynamic change of conditions in the economy (new technologies, information, etc.), this is of unusual importance.

\section{EFFECT ON PRICES}

A successful exchange rate policy should simultaneously ensure that domestic prices are at a standstill, without exporters' competitiveness being reduced. In the event that domestic inflation is higher than in the world, these goals become conflicting, because the first unequivocally means that the nominal market rate should be stable, while the second goal would require that the real exchange rate be stable, which means that the first goal give up, and the market rate begins to de-press permanently.

\section{TRANSMISSION PROCESSES}

The processes of globalization of financial markets have, on the one hand, intensified the flow of capital, as the most mobile factor of production, through global financial flows and, on the other hand, increased the sensitivity of national economies to regional and global economic and political trends. The probability of transmission of instability and crisis from "infected" to a relatively healthy, but weakened immune system, the national economy is higher if the degree of foreign trade and financial connection of economies is higher. Trade transmission is realized through the foreign trade balance, prices of goods and services, competitiveness and exchange rate, while the prices of financial instruments, prices and quality of banking products, interest rates, market liquidity and also the exchange rate of the financial transmission lever. Research done so far with the intention of examining the intensity and direction of transmission processes has shown that the degree of transmission is higher at the intraregional than at the interregional level. Also, the positive effects of favorable economic and political developments in developed countries are more used by other developed countries, while the consequences of unfavorable economic and political developments in developed countries are borne by both developed and emerging markets. Finally, the multiplication of instabilities and crises in developing countries is largely done within regions with emerging markets. Given that new financial markets are very sensitive to economic and financial disruptions at the regional and global level, timely detection of threats from instability and crisis and response to signals can greatly contribute to preventing or, at least, reducing the intensity of the crisis 


\section{IMPACT ON ECONOMIC SYSTEM}

The exchange rate is complex and multidimensional. It radiates in many directions and produces effects that are manifested in various ways in certain parts of the economic system. In some parts the effects of any set course will be desirable and favorable, and in other segments they will simply be qualified as undesirable and harmful. There will also be such areas where the effects of the course will encounter completely different, literally contradictory assessments. There is no single course that equally well, or even unequally purposefully satisfies all the requirements that are set before it by the logic of macroeconomic desideratums. A further aspect of the exchange rate stems from the fact that it is in fact one price, and perhaps the most important price in the overall market system. The important fact is that the exchange rate directly affects a wide range of domestic prices, and indirectly affects all prices.

Special emphasis should be placed on the two undoubtedly most important goals of exchange rate policy: competitiveness and price stability. In theory, the most general goal of exchange rate policy is to maximize these two goals with a satisfactory balance of payments and flexibility. However, the achievement of these two basic goals is not only incompatible, but they are in direct conflict76 from the point of view of exchange rate policy.

\section{STABILITY OF EXCHANGE RATE AND IT'S IMPACTS}

Exchange rate stability is one of the basic preconditions for general macroeconomic stability. Without exchange rate stability, there is no price stability, which then throws the entire macroeconomic system out of equilibrium. Since the economy must be in equilibrium at all times, it (equilibrium) is established on a new, less favorable level. This is especially pronounced in economies with a high degree of openness. In general, the requirement for exchange rate stability aims to create an optimal environment for the functioning of the entire economy. General believe is that it should be emphasized that the requirement for exchange rate stability is not a requirement for its invariability.

\section{THE MOST DIRECT IMPACT}

of the exchange rate has on the economic growth of a country by influencing foreign trade. One of the ways in which foreign trade drives economic growth is through technological progress, which is a natural consequence of international trade. When a country is open to international trade and competes in the global market, it is natural to adopt the most advanced production technologies and management techniques, engage the most qualified human resources and invest in sophisticated research and development (R\&D). Increasing efficiency in terms of cost and volume, in turn, can improve production factors - labor and capital.

\section{THE REAL EXCHANGE RATE}

is a good indicator of the export competitiveness of one country, showing the ratio of prices of goods and services in one to prices in other countries. Undervaluation of the domestic currency is a situation when the nominal exchange rate is above the real one, then we are talking about a real depreciation. With an undervalued exchange rate, purchasing power in the country is higher than abroad. Due to the high price of foreign currency, imports are becoming more expensive, which further leads to an increase in demand for domestic products, and a decrease in demand for imported products. Exporters get more domestic money, which increases the export of products and increases competitiveness in foreign markets. Such developments result in an improvement in the balance of payments. According to traditional Keynesian macroeconomics, relative depreciation encourages exports, making them more profitable, which further encourages companies to increase their exports. Since the demand for export products is relatively elastic in terms of prices, an increase in the volume of exports leads to an increase in export earnings, and thus total income and employment.

In contrast, if the exchange rate is below the level of the real exchange rate, the domestic currency is overvalued and the foreign currency is undervalued. The overvaluation of the domestic currency means that the purchasing power abroad is higher than in the country. Prices of foreign goods converted into domestic currency at such an exchange rate become lower, so there is interest in importing goods because imports become relatively cheap. Foreign goods, which would be too expensive for the average consumer at the real exchange rate, become competitive on the domestic market with a lower exchange rate, which, naturally, leads to a decrease in domestic production. Conversely, products that a given economy could export at a real exchange rate become too expensive, therefore uncompetitive in foreign markets. The overestimated exchange rate enables domestic consumers and producers to rely on imports, but it has a very negative effect on the export capacities of a given economy. Over time, imports exceed exports and contribute to foreign exchange outflows. This, in turn, leads to less and less opportunities to buy goods from abroad and more and more difficult repayment of loans for servicing foreign debt. The strongest world currencies are mainly traded on the foreign exchange market. The dollar is still the most traded currency (in 2004, the dollar was one of the currencies in $89 \%$ of all foreign exchange transactions), but its relative share declined slightly (in 2001, its share was 90\%). After the dollar, the most traded currencies in 2004 were the euro (37\%) and the yen $(20 \%)$ and the pound $(17 \%)$.

For a long time, in economic circles, there was an opinion that macroeconomic variables have the greatest (decisive) influence on the movement of exchange rates. In this regard, a large number of theories have been developed that deal with this problem. Within these theories, variables such as: inflation, interest rates, money supply, balance of payments, gross domestic product growth, (unemployment), foreign exchange reserves, productivity and others lead to changes in the exchange rate of one currency to another. Let us briefly consider some of the simpler versions of these theories without intending to analyze them in depth. Probably the most commonly used theory of purchasing power parity is that the exchange rate is formed at the level at which purchasing power is equalized in the country and abroad. Thus, the exchange rate is formed as the ratio of the average price level of a basket of goods in the country with the relevant prices abroad. According to this theory, inflation has a decisive influence on the exchange rate. 
According to the balance of payments theory, the exchange rate is formed at the level at which the balance of payments is balanced. Consequently, the growth of the balance of payments (trade) deficit will lead to a fall in the exchange rate of the country with this deficit. Also relevant is the theory that exchange rate movements are closely related to financial asset markets, especially stocks. The attractiveness of the stock market brings with it the growth of the currency of a country that has a strong stock market. Likewise, GDP growth or employment growth leads to the strengthening of the currencies of the countries in which this growth was recorded.

\section{INFLATION INDICATORS}

Traders are watching the development of inflation carefully because the choice of methods to fight inflation raises interest rates, and higher interest rates tend to support the domestic currency. Traders use the following economic instruments to measure inflation. Industrial Price Index (PPI). It is made up of most sectors of the economy, such as manufacturing, mining and agriculture. Unlike the consumer price index, the industrial price index does not include imported goods, services or taxes. Consumer Price Index (CPI). It reflects the average change in retail prices of a fixed consumer basket of goods and services. CPI data is made up of price samples for food, shelter, clothing, fuel, transportation, and health care that people buy on a daily basis. These two indices, the PPI and the CPI, are instruments that help traders measure inflation activity, although the Federal Reserve is of the opinion that the indices overestimate the strength of inflation.

\section{TRADE BALANCE}

This is one of the most important economic indicators. Its value can cause long-term changes in monetary and foreign policy. The trade balance consists of the net difference between exports and imports of a particular economy.

The data include six categories:

1. food,

2. raw materials and industrial stocks,

3. consumer goods,

4. cars,

5. capital goods,

6 . other goods.

\section{EMPLOYMENT INDICATORS}

The employment rate is an economic indicator that is important in several areas. Of course, the employment rate measures the soundness of the economy. The unemployment rate is an economic indicator that is lagging behind. This is an important feature to remember, especially in times of economic recession. While people focus on the health and recovery of the work sector, employment is the last economic indicator to recover. When economic activities lead to job losses, it takes time to create psychological confidence in economic recovery at the managerial level before new jobs are created. At the individual level, improvements in job appearance may be disguised when new jobs are opened in small companies and thus not fully reflected in the data. Employment reports are important for financial markets in general and foreign exchange in particular.

\section{CONSUMER INDICATOR}

Retail is a significant indicator of consumer spending for foreign exchange traders because it shows the strength of consumer demand as well as consumer confidence. It is a component for calculating other economic indicators, such as GDP.

\section{RETAIL}

Retail is a significant indicator of consumption for foreign exchange traders because it shows the strength of consumer demand as well as consumer confidence. Retail is especially important as an economic indicator in the United States. Unlike other countries such as Japan, the focus of the American economy is the consumer. If the consumer has sufficient discretionary income, or sufficient credit, then more goods will be produced or imported. Retail numbers create an economic process of "dripping" in the manufacturing sector. The seasonal aspect is important for this economic indicator. The months of retail that foreign exchange traders watch the most are December, due to the holidays, and September, the month of returning to schools. November is becoming an increasingly important month as a result of the change in pre-Christmas shopping to pre-December shopping. Another interesting phenomenon has occurred in the United States. Despite the economic recession of the early 1990s, retail sales were unusually high. However, the profit margin was much thinner. The reason is consumers turning to discount stores. Traders closely monitor retail to measure the strength of the economy and thus the strength of the currency. This indicator is published on a monthly basis.

\section{CONSUMER EXPECTATIONS}

It is a household survey designed to measure the direct individual propensity to spend money to increase or maintain the same level of costs associated with meeting current household needs and, implicitly, the labor market situation.

\section{CONCLUSION}

In order to create a competitive foreign exchange market and form an exchange rate that is the result of real market relations, it is necessary to reduce the role of the domestic national bank in the foreign exchange market. This would mean abandoning the previous policy of, say, exchange rate stability, given that the defense of the national currency in this case and in this way is extremely expensive because it consumes foreign exchange reserves and leads to further borrowing. In that case, the National Bank would intervene only occasionally in the foreign exchange market, when there is a need to prevent extreme exchange rate fluctuations. The National Bank should take responsibility for inflation within certain limits, while determining the exchange rate 
of the domestic currency should be left to the market. A fixed exchange rate would bring lower interest rates, lower risk and less business uncertainty, but the state would thus deplete foreign exchange reserves. On the other hand, a completely free exchange rate of the national currency would lead to a (real) fall of the same, which in some period would certainly lead to a significant increase in exports, but the consequences for businessmen and citizens who have loans linked to foreign exchange rates, say USD or eur, were catastrophic.

The exchange rate should be as close as possible to the real value, and deviations from the real one should have a tendency to underestimate, not overestimate the domestic currency, which would stimulate exports, because only the expansion of exports can provide a country out of the crisis. In parallel with the easing of the intervention of the national bank, due to the possible domestic currency in the coming period, the problem of the expected possible huge foreign currency loans of citizens and companies should be approached. All entities should participate in the resolution - debtors, commercial banks, state representatives, the national bank of the given state.

\section{AUTHORS}

First Author - Salahedeen Ramadan Azwali, Phd. candidate 